\title{
Coomb's Test Negative Autoimmune Hemolytic Anemia
}

\author{
Ajaya kumar Dhakal $M D^{l}$, Devendra Shrestha $M D^{1}$, Subhash Chandra Shah $M D^{l}$. \\ ${ }^{1}$ Department of Pediatrics, KIST Medical College.
}

\begin{abstract}
:
Autoimmune hemolytic anemia is uncommon type of anemia in children. High degree of clinical suspicion along with detailed investigations is required for diagnosis. It is characterized by anemia and positive direct antiglobulin test along with features of hemolysis. Infrequently direct antiglobulin test may be negative in autoimmune hemolytic anemia and may pose diagnostic difficulty. We report a 14 year-old female with two acute episodes of severe anemia along with splenomegaly, reticulocytosis, unconjugated hyperbilrubinemia and negative direct antiglobulin test. She was successfully treated with oral prednisolone. Serum Vitamin B12 level was low in this patient and association between autoimmune hemolytic anemia and Vitamin B12 deficiency could not be explained.
\end{abstract}

Keywords: autoimmune hemolytic anemia; direct antiglobulin test; vitamin B12 deficiency.

\section{INTRODUCTION}

Autoimmune hemolytic anemia (AIHA) are group of clinical conditions characterized by production of autoantibodies directed against RBC membrane antigen leading to its premature destruction. ${ }^{1}$ These are uncommon causes of anemia in children ${ }^{1,2}$ and should be considered in a differential diagnosis of acquired hemolytic anemia or secondary manifestations of autoimmune diseases, lymphoproliferative disease and viral or mycoplasma infections.

Here, we report a case of a 14 year-old girl with Coomb's negative autoimmune hemolytic anemia which responded with prednisolone and had lab evidence of Vitamin B12 deficiency.

\section{CASE REPORT}

A 14 year-old girl was presented to emergency with fever for 14 days, vomiting for 3 days, paleness of body for three days and passing of dark colored urine for one day. She was under oral ofloxacin for last five days from a private clinic. There was no history of seizure, blood transfusion, skin rashes, joint pain, bleeding from any site and family history of bleeding problems. On examination child was pale, icteric, pyrexic and was in shock with normal systemic examination except for palpable spleen. There was no evidence of KayserFleischer ring on ophthalmological examination. She was successfully resuscitated. Her investigationsare shown in Table 1. The child was diagnosed with acute hemolytic anemia secondary to infection and was treated with intravenous antibiotics, blood transfusions and empiric antimalarial treatment however we could not perform IgM serology, seroconversion identification for mycoplasma, Epstein-Barr virus, cytomegalovirus and parvovirus to prove such infection. The child was discharged after eight days of hospital admission and had hemoglobin, WBC with absolute neutrophils count and platelet count normal at regular follow up.

\section{Correspondence:}

Dr. Ajaya Kumar Dhakal, Department of Pediatrics,

KIST Medical College, Imadol , Lalitpur

Phone No.: 9841316649

Email : ajayakdhakal@gmail.com. 
Table 1: Investigations

\begin{tabular}{|c|c|c|}
\hline Investigation & First Admission & Second Admission \\
\hline Hemoglobin & $7.6 \mathrm{~g} / \mathrm{dl}$ & $6.0 \mathrm{~g} / \mathrm{dl}$ \\
\hline PBS & $\begin{array}{l}\text { Normocytic normochromic } \\
\text { RBC, anisocytosis, } \\
\text { polychromatophils. } \\
\text { No abnormal cells and } \\
\text { hemoparasites }\end{array}$ & $\begin{array}{l}\text { Microcytic hypochromic RBC, } \\
\text { anisocytosis, few microspherocytes, } \\
\text { polychromatophil, no abnormal cells } \\
\text { and hemoparasites }\end{array}$ \\
\hline Reticulocyte count & $7.6 \%$ & $16 \%$ \\
\hline TLC & $5400 / \mathrm{mm}^{3}$ & $5200 / \mathrm{mm}^{3}$ \\
\hline Platelet count & $237000 / \mathrm{mm}^{3}$ & $251000 / \mathrm{mm}^{3}$ \\
\hline ESR & $75 \mathrm{~mm} / \mathrm{hr}$ & $57 \mathrm{~mm} / \mathrm{hr}$ \\
\hline $\mathrm{MCV} / \mathrm{RDW}$ & & $152 \mathrm{fl} / 23.9 \%$ \\
\hline RBC count & & $1200000 / \mathrm{mm}^{3}$ \\
\hline Direct and Indirect Coomb's test & Negative & Negative \\
\hline Total Bilirubin & $2.7 \mathrm{mg} / \mathrm{dl}$ & $3.78 \mathrm{mg} / \mathrm{dl}$, indirect $2.58 \mathrm{mg} / \mathrm{dl}$ \\
\hline S. Protein / S. Albumin & $5.5 \mathrm{~g} / \mathrm{dl} \quad / \quad 2.8 \mathrm{~g} / \mathrm{dl}$ & $8 \mathrm{~g} / \mathrm{dl} / 3.6 \mathrm{~g} / \mathrm{dl}$ \\
\hline Bone marrow aspiration cytology & & $\begin{array}{l}\text { Normocellular with erythroid } \\
\text { hyperplasia }\end{array}$ \\
\hline S. Iron & & $26 \mathrm{mcg} / \mathrm{dl}(37-145 \mathrm{mcg} / \mathrm{dl})$ \\
\hline S. Ferritin & & $585 \mathrm{ng} / \mathrm{ml}(6-350 \mathrm{ng} / \mathrm{ml})$ \\
\hline Total iron binding capacity & & $238 \mathrm{mcg} / \mathrm{dl}(210-340 \mathrm{mcg} / \mathrm{dl})$ \\
\hline S. Ceruloplasmin & & $29.4 \mathrm{mg} / \mathrm{dl}(22-61 \mathrm{mg} / \mathrm{dl})$ \\
\hline S. Haptoglobin & & $33 \mathrm{mg} / \mathrm{dl}(30-200 \mathrm{mg} / \mathrm{dl})$ \\
\hline S. Vitamin B12 level & & $154.5 \mathrm{pg} / \mathrm{ml}(200-1100 \mathrm{pg} / \mathrm{ml})$ \\
\hline USG abdomen & Normal & Splenomegaly \\
\hline HAMS test & & Negative \\
\hline $\begin{array}{l}\text { Thyroid function test, Hemoglobin } \\
\text { electrophoresis, Sickle cell analysis }\end{array}$ & & Normal \\
\hline HBsAg, HCV, HIV serology & & Negative \\
\hline \multicolumn{3}{|c|}{$\begin{array}{l}\text { Prothrombin time, Absolute neutrophil count, G6PD, Liver enzymes, Renal function tests and X-ray chest } \\
\text { were normal in both the admissions. }\end{array}$} \\
\hline
\end{tabular}

Ten months after remaining asymptomatic with normal hemoglobin level, she presented again with complaints of dizziness, headache, vomiting, and decreased urine output for one day. On examination child was pale, icteric with normal vitals and normal systemic examination except for palpable spleen and livedo reticularis in lower limbs. Her investigations were shown in Table 1. In addition, reactive lymphocytes with clumping of RBCs in room temperature were seen in peripheral smear indicating the possibility of cold agglutination. During hospital stay, she developed high grade fever with serial decrease in hemoglobin level. The child was transfused with packed RBC along with intravenous antibiotics and was also treated with Vitamin B 12 with no further improvement in hemoglobin level. The clinical course, examination finding and investigation reports were suggestive of immune mediated hemolytic anemia probably primary in origin. Thus oral prednisolone was started with which her hemoglobin level raised consistently and did not require further transfusions. The child went into remission after six weeks of daily steroid followed by slow tapering over month. At present the child is on regular follow up with normal hemoglobin level without any steroids. 


\section{DISCUSSION AND REVIEW OF LITERATURE}

Immune hemolytic anemia can be classified to autoimmune, alloimmune and drug-induced. Autoimmune hemolytic anemia is further classified into warm AIHA, cold agglutinin syndrome, paroxysmal cold hemoglobinuria, mixed type AIHA and drug-induced AIHA based on nature of antibodies, while they are classified as primary (idiopathic) and secondary (manifestation of another disease) based on etiology. ${ }^{1}$

The diagnosis of AIHA is based on hemoglobin concentration less than $11 \mathrm{~g} / \mathrm{dL}$, a positive direct antiglobulin test (DAT) and at least one of the following features of hemolysis: reticulocyte count greater than $120 \times 10^{9} / \mathrm{L}$, haptoglobin less than $10 \mathrm{mg} / \mathrm{dL}$, and total bilirubin greater than $1 \mathrm{mg} / \mathrm{dL} .{ }^{2}$ A positive DAT suggests diagnosis of AIHA however DAT negative AIHA occurs in $5-10 \%$ of patients. ${ }^{3,4}$ AIHA with negative DAT are uncommon and requires investigations to exclude secondary causes and regular follow up as it is difficult to establish that hemolysis is due to autoimmune etiology. ${ }^{3}$ Negative DAT may be due to presence of IgG autoantibodies in quantities lesser than detectable threshold for DAT, IgA or IgM autoantibodies and low affinity autoantibodies. ${ }^{4}$ The Natural killer cell mediated antibody independent cytotoxicity also has been postulated in the pathogenesis of AIHA which may also contribute to negative DAT. ${ }^{4}$ The DAT in developing countries is done by conventional tube method which has low sensitivity that may cause false negative DAT and delays the diagnosis. ${ }^{5}$ However repeat DAT done by gel technique was also negative in our patient as in some cases, repeat evaluation of DAT may show positive result. ${ }^{6}$ There is no single optimal test for investigation of AIHA with negative DAT and there is need for combination of tests to detect different antibodies. ${ }^{7}$ Such combination of techniques includes flow cytometry, enzyme linked antiglobins test, solid phase or direct polybrene. ${ }^{7,8}$ However these techniques are expensive and are not easily available in our country. Despite the difference in pathologic mechanisms in DAT positive and negative AIHA, there is no difference in terms of effectiveness of steroid therapy, survival at one year and long term complications between these two conditions. ${ }^{9}$ However, patients with DAT negative AIHA clinically have milder degree of hemolysis and require low doses of steroids for maintenance as compared to patients with DAT positive AIHA. ${ }^{9}$ Due to lack of facilities, serological tests for Epstein-Barr virus, Mycoplasma, Parvo virus and Cytomegalovirus could not be performed which was the main limitation. These serological tests are considered important to exclude AIHA secondary to these infections. ${ }^{2}$ AIHA secondary to infections was considered less likely in this patient due to compatible clinical picture and recurrent acute hemolysis. ${ }^{2}$ There was unusual finding of Vitamin B12 deficiency in our patient. Despite treatment with Vitamin B12, there was no clinical improvement and only after initiation of oral prednisolone, hemolytic activity was reduced thus obviating need for further transfusions. Vitamin B12 deficiency has been reported to cause hemolytic anemia. ${ }^{10}$ However it is unlikely to be a primary cause of hemolysis in this child and the authors could not find the literature regarding association of Vitamin B12 deficiency with autoimmune hemolytic anemia.

In conclusion, high degree of clinical suspicion of autoimmune hemolytic anemia should be made in patients presenting with acute hemolysis and should be diagnosed after exclusion of secondary causes by appropriate investigations including DAT. Negative DAT does not rule out possibility of AIHA and in such cases compatible clinical course help in diagnosis of AIHA as demonstrated in this patient.

\section{REFERENCES}

1. Gehrs BC, Friedberg RC. Autoimmune hemolytic anemia. American Journal of Hematology. 2002;69(4):258-71. http://dx.doi.org/10.1002/ ajh.10062 PMid:11921020.

2. Aladjidi N, Leverger G, Leblanc T, Picat MQ, Michel G, Bertrand Y, et al. New insights into childhood autoimmune hemolytic anemia: a French national observational study of 265 children. Haematologica. 2011;96(5):655-63. http://dx.doi.org/10.3324/haematol.2010.036053. PMid:21228033

3. Telio D, Pi D, Zalunardo N, Tucker LB, Chen LY. Atypical autoimmune hemolytic anemia. Haematologica. 2011;96(11):e43. http:// dx.doi.org/10.3324/haematol.2011.050724. PMid:22058281 PMCid:PMC3208669

4. Garratty G. Immune hemolytic anemia associated with negative routine serology. Seminars in hematology. 2005;42(3):156-64. http://dx.doi. org/10.1053/j.seminhematol.2005.04.005. PMid:16041665

5. Gupta R, Singh DK, Singh S, Singh T. Coomb's negative autoimmune hemolytic anemia: a diagnostic dilemma for the 
hematologist. Indian journal of pathology \& microbiology. 2008;51(4):571-2. http://dx.doi. org/10.4103/0377-4929.43771. PMid:19008606

6. Sarper N, Caki Kilic S, Zengin E, Aylan Gelen S. Management of autoimmune hemolytic anemia in children and adolescents: A single center experience. Turkish Journal of Hematology. 2011;28(3):198-205. http://dx.doi.org/10.5152/ tjh.2011.54.

7. Leger RM, Co A, Hunt P, Garrity G. Attempts to support an immune etiology in 800 patients with direct antiglobulin test-negative hemolytic anemia. Immunohematology / American Red Cross. 2010;26(4):15660. PMID:22356452.

8. Alwar V, Shanthala DA, Sitalakshmi S, Karuna RK. Clinical patterns and hematological spectrum in autoimmune hemolytic anemia. Journal of laboratory physicians. 2010;2(1):17-20. PMID: 21814401;

9. Kamesaki T, Toyotsuji T, Kajii E. Characterization of direct antiglobulin test-negative autoimmune hemolytic anemia: a study of 154 cases. American journal of hematology. 2013;88(2):93-6. http:// dx.doi.org/10.1002/ajh.23356. PMid:23169533

10. Acharya U, Gau JT, Horvath W, Ventura P, Hsueh CT, Carlsen W. Hemolysis and hyperhomocysteinemia caused by cobalamin deficiency: three case reports and review of the literature. Journal of hematology \& oncology. 2008;1:26. PubMed PMID: 19094231. 